\title{
Irrigation with drainage solutions improves the growth and nutrients uptake in Juncus acutus
}

\author{
Pedro García-Caparrós ${ }^{\mathrm{a}}$, Alfonso Llanderal ${ }^{\mathrm{a}}$, Ahmed El-Tarawy $^{\mathrm{b}}$, Pedro José Correia ${ }^{\mathrm{c}}$, \\ Maribela Pestana ${ }^{c}$, María Teresa Lao ${ }^{\mathrm{a}, *}$ \\ a Higher Engineering School, Department of Agronomy of the University of Almeria, Agrifood Campus of International Excellence CeiA3, Ctra. Sacramento \\ s/n, La Cañada de San Urbano, 04120, Almería, Spain \\ ${ }^{\mathrm{b}}$ Department of Agriculture, Kafrelsheikh University, Egypt \\ c Universidade do Algarve, MeditBio, FCT, Edificio 8, Campus de Gambelas, 8005-139 Faro, Portugal
}

\section{A R T I C L E I N F O}

\section{Article history:}

Received 29 January 2016

Received in revised form 17 June 2016

Accepted 20 June 2016

Available online 2 July 2016

\section{Keywords:}

Biomass

Electrical conductivity

Leachate

Macrophyte

Nutrient use efficiency

Ornamental cascade crop system

\begin{abstract}
A B S T R A C T
The potential contamination of surface and ground water by the nurseries in the Mediterranean area obligates the use of novel systems such as the cascade cropping system. The aim of this work was to evaluate the effects of drainage water derived from an ornamental (Ruscus aculeatus L. and Maytenus senegalensis (Lam.) Exell.) cascade crop system on the growth and polluting elements uptake ( $\mathrm{N}$ and $\mathrm{P}$ ) against a standard nutrient solution in Juncus acutus L. plants. The experiment consisted of three treatments: a standard nutrient solution $\left(\mathrm{T}_{0 \mathrm{~J}} ; \mathrm{EC}=150 \mathrm{mS} \mathrm{m}^{-1}\right), 1: 2$ diluted drainage water $\left(\mathrm{T}_{1 \mathrm{j}} ; \mathrm{EC}=245 \mathrm{mS} \mathrm{m}^{-1}\right)$ and the raw drainage water $\left(\mathrm{T}_{2 \mathrm{~J}} ; \mathrm{EC}=310 \mathrm{mS} \mathrm{m}^{-1}\right)$. Biomass, plant and substrate parameters and total $\mathrm{N}$ and $P$ uptake by plants were determined at the beginning and at the end of the experiment. This experiment showed that the irrigation with diluted and raw drainage water $\left(T_{1 J}\right.$ and $\left.T_{2 J}\right)$ with lower concentrations of $\mathrm{N}$ and $\mathrm{P}$ compared to the control treatment $\left(\mathrm{T}_{0 \mathrm{~J}}\right)$ supposed an increase of biomass and consequently the increase of $\mathrm{N}$ and $\mathrm{P}$ uptake, where the plants irrigated with higher EC (raw drainage water) showed the highest biomass and total $\mathrm{N}$ and $\mathrm{P}$ uptake.
\end{abstract}

(c) 2016 Elsevier B.V. All rights reserved.

\section{Introduction}

Nowadays, the continuous growth of the ornamental plant industry over the world and in the southern of Spain has brought about mounting concern over the nutrients ( $\mathrm{N}$ and $\mathrm{P}$ ) leached from the containers and its potential contamination of the surface and ground water (Lao, 2005). The drainages are normally rich in nutrients, but they are not balanced; moreover, the levels of $\mathrm{Na}^{+}$and $\mathrm{Cl}^{-}$are high for the sensitive cultures (Carrion et al., 2005). The nitrate is leached from most of the mineral soils and container

Abbreviations: AG, aboveground; BG, belowground; DW, dry weight; EEA, european environmental agency; Tf, final plants; FW, fresh weight; HPLC, high performance liquid cromatography; Ti, initial plants; IFDM, integrated farm drainage management; LSD, least significant difference; PAR, photosynthetically active radiation; $\mathrm{RH}$, relative humidity; SBC, serial biological concentration; ANOVA, standard analysis of variance.

* Corresponding author.

E-mail addresses: pedrogar123@hotmail.com (P. García-Caparrós), alfonsollanderal@hotmail.com (A. Llanderal), tarawy101@yahoo.com (A. El-Tarawy), pcorreia@ualg.pt (P.J. Correia), fpestana@ualg.pt (M. Pestana), mtlao@ual.es (M.T. Lao). media (Handreck and Black, 1984) and although the phosphate is considered rather immobile within many soils, it is much more readily leached from the container media composed of pine bark or spaghnum peatmoss (Yeager and Barrett, 1984). Both nutrients are of particular concern because of their capacity to lead to eutrophication in waterways (Kim et al., 2003; Taylor et al., 2005). Therefore, taking into account existing legislation such as the Nitrates Directive (91/676/EEC) and the Drinking Water Directive (98/83/EC) which set a maximum allowable concentration for nitrate $\left(\mathrm{NO}_{3}{ }^{-}\right)$of $50 \mathrm{mg} \mathrm{L}^{-1}$ and European Environmental Agency (EEA) (2005) which established a range of phosphorus (P) of $25-50 \mu \mathrm{g} \mathrm{L}^{-1}$ in water, it would be advisable to reduce the environmental pollution through systems compatible with the environment.

The Integrated Farm Drainage Management (IFDM) systems employ sequential reuse of water with the biomass production to help control saline groundwater, the reduction of the wastewater and chemicals and improving the sustainability of arid land irrigated agriculture (Blunk et al., 2005). One example of these systems can be a Serial Biological Concentration (SBC) or a cascade cropping system where the drainage water collected from beneath one crop is used to irrigate the next more salt tolerant crop in the series trying to reduce almost entirely the drainage volume from the last 
crop (Incrocci et al., 2003). Under the IFDM systems, an important strategy could be the growth of macrophytes as last crop in the series due to its potential to remove the nitrogenous compounds and phosphorus from the wastewater and incorporate them into the plant biomass (Brix, 1991), as have been reported in previous researches with species within Juncaceae such as J. kraussii, with a significant potential to remove $\mathrm{N}$ from highly saline wastewater (Brown et al., 1999; Lymbery et al., 2006) and J. amabilis and J. flavidus with a great effectiveness at retention of $\mathrm{N}$ and $\mathrm{P}$ (Read et al., 2008).

The adaptability of macrophytes to salinity is variable and species-dependent (Mufarrege et al., 2011), so it could be reasonable taking into account the use of a native macrophyte from the Mediterranean area which has a high degree of soils and groundwater salinization (Lambers, 2003).Juncus acutus L. is an evergreen halophytic macrophyte perennial herb belonging to the family Juncaceae (Balslev, 1996) widely distributed in salt marshes or poorly-drained soils (El-Shamy et al., 2012) and can be found in the Spanish coastal marsh communities and in several estuaries of the Iberian Peninsula (Sainz and Ruiz, 2006). Moreover this specie has a wide ecological range, tolerating the soils with high levels of sulphates and chlorides (Fernández-Carvajal, 1982). Cylindrical leaves and stems (culms) with a sharp point on top emerge from the rhizome in bundles and can reach $1 \mathrm{~m}$ in height. During late spring/summer, the flowering panicles occur sub-terminally on stems. The seeds (nuts) are protected within the inflorescence and may stay on the plant for 6 or more months before being dispersed by the wind (Greenwood and MacFarlane, 2009).

Although much has been published about the use of macrophytes to remove $\mathrm{N}$ and $\mathrm{P}$ in municipal, industrial, agricultural wastewaters and stormwater runoff (Vymazal, 2007), very little is known about their use as an ornamental cascade crop system under greenhouse conditions. Therefore, in the present research, a pot experiment with $J$. acutus under greenhouse conditions was established in order to determine the potential to remove nitrogen and phosphorus in diluted or raw drainage from an ornamental cascade cropping system including Ruscus aculeatus L. and Maytenus senegalensis (Lam.) Excell.

\section{Material and methods}

\subsection{Site specifications and plant material}

The experiment was conducted at the University of Almería $\left(36^{\circ} 49^{\prime} \mathrm{N}, 2^{\circ} 24^{\prime} \mathrm{W}\right)$.

Rooted cutting of $J$. acutus L. were acquired in trays with plugs of $0.2 \mathrm{~L}$ from a commercial nursery. Each plant was transplanted into $1.5 \mathrm{~L}$ polyethylene pots filled with a mixture of sphagnum peatmoss and Perlite 80:20 (v/v) and subjected to nutrient solution treatments for 8 weeks (average time to produce saleable nursery crops in pots of $1.5 \mathrm{~L}$ following the advices given by local growers). The pots were placed on plastic trays to collect the drainages and covered with galvanized wire to impede that the pots were in contact with the drainages. On this mesh of wire black/white, smooth plastic sheeting was placed to avoid the evaporation; the black side of the film could avoid the mould fungus and algae growth and the white side reflects the sun and reduces the condensation and heat build-up. During the experiment, plants were grown in a greenhouse of $150 \mathrm{~m}^{2}$. The microclimatic conditions inside the greenhouse for the experimental period, monitored continuously with HOBO SHUTTLE sensors (model H 08-004-02, Onset Computer Crop., Bourne, MA) showed a daily average temperature of $17.1^{\circ} \mathrm{C}$, relative humidity $(\mathrm{RH})$ of $65.6 \%$ and photosynthetically active radiation (PAR) of $71.6 \mu \mathrm{mol} \mathrm{m}^{-2} \mathrm{~s}^{-1}$.
Table 1

Chemical composition of nutrient solutions of each treatment: $T_{0 J}$ - standard nutrient solution, $\mathrm{T}_{1 \mathrm{~J}}-1: 2$ diluted drainage water, and $\mathrm{T}_{2 \mathrm{~J}}-$ raw drainage water. $\mathrm{EC}$ was expressed in $\mathrm{mS} \mathrm{m}^{-1}$ and nutrient concentration in $\mathrm{mg} \mathrm{L}^{-1}$. In $\mathrm{T}_{1 \mathrm{~J}}$ and $\mathrm{T}_{2 \mathrm{~J}}$, the values are the means \pm standard deviation in each treatment during all experiment ( 8 weeks).

\begin{tabular}{lccc}
\hline Parameters & \multicolumn{1}{c}{$\mathrm{T}_{\text {0J }}$} & \multicolumn{1}{l}{$\mathrm{T}_{1 \mathrm{~J}}$} \\
\hline $\mathrm{pH}$ & 6.50 & $7.50 \pm 0.24$ & $7.50 \pm 0.38$ \\
$\mathrm{EC}$ & 150 & $245 \pm 31$ & $310 \pm 28$ \\
$\mathrm{~N}$ & 84.00 & $46.76 \pm 9.745 .50$ & $58.24 \pm 8.02$ \\
$\mathrm{P}$ & 21.70 & $5.86 \pm 0.53$ & $9.61 \pm 2.10$ \\
$\mathrm{Cl}$ & 122.50 & $687.40 \pm 72.53$ & $789.25 \pm 69.76$ \\
$\mathrm{~S}$ & 64.00 & $129.60 \pm 10.74$ & $166.08 \pm 9.84$ \\
$\mathrm{Ca}$ & 80.00 & $610.40 \pm 83.30$ & $648.80 \pm 67.07$ \\
$\mathrm{Mg}$ & 33.60 & $125.04 \pm 11.23$ & $137.52 \pm 12.57$ \\
$\mathrm{~K}$ & 117.00 & $202.02 \pm 26.83$ & $265.98 \pm 29.18$ \\
$\mathrm{Na}$ & 59.80 & $509.91 \pm 74.60$ & $589.72 \pm 66.08$ \\
\hline
\end{tabular}

\subsection{Experimental design and treatments}

The experiment consisted of three treatments using different nutrient solutions: $\mathrm{T}_{0 \mathrm{~J}}\left(150 \mathrm{mS} \mathrm{m}^{-1}\right.$; a standard nutrient solution or control) reported by Jiménez and Caballero (1990) for an adequate growth of ornamental plants under Mediterranean conditions and was derived from tap water and $\mathrm{H}_{3} \mathrm{PO}_{4}, \mathrm{HNO}_{3}$ and $\mathrm{KNO}_{3}$ supplies), $\mathrm{T}_{1 \mathrm{~J}}\left(245 \mathrm{mS} \mathrm{m}^{-1} ; 1: 2\right.$ diluted drainage water) and $\mathrm{T}_{2 \mathrm{~J}}\left(310 \mathrm{mS} \mathrm{m}^{-1}\right.$; raw drainage water). The nutrient solutions used to irrigate the plants every day were prepared weekly. The drainage water of $R$. aculeatus irrigated with the standard nutrient solution (the same as $\mathrm{T}_{0 \mathrm{~J}}$ ) was collected weekly. Then, this drainage water was used to elaborate weekly two different nutrient solutions: $\mathrm{T}_{1 \mathrm{M}}$ (1:2 diluted drainage water with tap water with the following composition: $64,122.50,80.00,33.60$ and $59.80 \mathrm{mg} \mathrm{L}^{-1}$ of $\mathrm{S}, \mathrm{Cl}, \mathrm{Ca}, \mathrm{Mg}$ and $\mathrm{Na}$; respectively, and EC of $90 \mathrm{mS} \mathrm{m}^{-1}$ ) and $\mathrm{T}_{2 \mathrm{M}}$ (raw drainage water) to irrigate daily each treatment of $M$. senegalensis (Lam.) Excell.; respectively. Finally, the leachates collected weekly from the irrigation of $M$. senegalensis ( $\mathrm{T}_{1 \mathrm{M}}$ and $\mathrm{T}_{2 \mathrm{M}}$ ) were used to irrigate daily each treatment of $J$. acutus; respectively $\left(\mathrm{T}_{1 \mathrm{~J}}\right.$ and $\mathrm{T}_{2 \mathrm{~J}}$ ) (Fig. 1). The experimental design consisted of three treatments $\left(\mathrm{T}_{0 \mathrm{~J}}, \mathrm{~T}_{1 \mathrm{~J}}\right.$ and $\left.\mathrm{T}_{2 \mathrm{~J}}\right)$, four blocks and four plants (one plant per pot) per block giving a total of 48 plants with a planting density of 10 plants $\mathrm{m}^{-2}$.

\subsection{Nutrient solutions determinations}

Four samples of nutrient solution per treatment were randomly collected weekly.

Each sample was composed by aliquots of $25 \mathrm{~mL}$, filtered through $0.45-\mu \mathrm{m}$ membrane filters and frozen until nutrient analyses were conducted. From each sample, electrical conductivity and $\mathrm{pH}$ values were determined by conductivity meter and $\mathrm{pH}$ meter (models Milwaukee C66 and pH52 (Milwaukee Instruments, USA), respectively); and the concentrations of nutrients were determined by HPLC (High Performance Liquid Chromatography; model Metrohm 883 Basic IC Plus, anions ion exchange column model Metrosep A SUPP 4, cations ion exchange column model Metrosep C4 100, IC conductivity detector range $(0-15000 \mu \mathrm{S} \mathrm{cm}-1)$, Metrohm AG, Switzerland) as described by Csáky and MartínezGrau (1998). The chemical composition of each treatment was presented in Table 1 . The increase of $\mathrm{pH}$ in 1:2 diluted and raw drainage water $\left(\mathrm{T}_{1 \mathrm{~J}}\right.$ and $\left.\mathrm{T}_{2 \mathrm{~J}}\right)$ compared to the control treatment can be can be related with the effect of substrate in leachate $\mathrm{pH}$ increasing their value as reported Merhaut et al., 2006. In addition, the 1:2 diluted and raw drainage water $\left(\mathrm{T}_{1 \mathrm{~J}}\right.$ and $\left.\mathrm{T}_{2 \mathrm{~J}}\right)$ showed lower $\mathrm{N}(1.8$ and 1.5-times) and $\mathrm{P}$ (3.7 and 2.2-times) concentrations compared to the control treatment $\left(\mathrm{T}_{0 \mathrm{~J}}\right)$, but higher $\mathrm{Na}$ (8.5 and 9.8-times) and $\mathrm{Cl}$ (5.6 and 6.5-times) concentrations and consequently higher EC compared to the control treatment $\left(\mathrm{T}_{0 \mathrm{~J}}\right)$. 


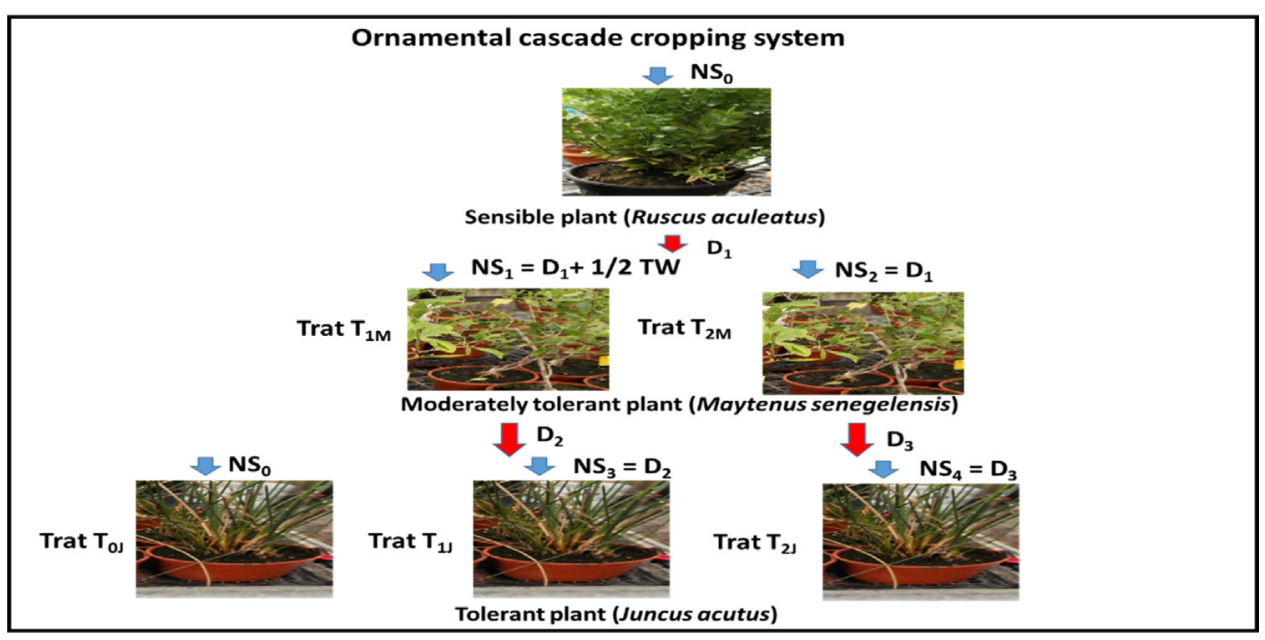

Fig. 1. Schematic layout of the ornamental cascade cropping system.

where NS is the nutrient solution supplied in each treatment, D is the drainage collected in each treatment and TW is the tap water.

\subsection{Plant parameters and biomass}

Prior to the initiation of the treatments and at the end of the experiment ( 8 weeks), four Juncus plants per treatment were randomly harvested and the substrate gently washed from the roots. The plants were divided into belowground (BG) and aboveground (AG) biomass and the respective fresh weights (FW) measured: the surface of the roots was dried with blotting paper prior to weighing. Belowground and aboveground biomass were then oven-dried at $60^{\circ} \mathrm{C}$ until a stable weight was reached in order to provide the respective dry weights (DW). The total biomass was calculated as the sum of BG and AG. The fresh and dry weights were expressed in $\mathrm{g} \mathrm{m}^{-2}$ because were multiplied by the planting density. The water content in AG, BG and total plant was calculated as indicated by Mateos-Naranjo et al. (2014) (FW-DW/FW) (-).

\subsection{Substrate parameters}

Prior to the initiation of the treatments and at the end of the experiment ( 8 weeks), four samples of substrate per treatment were randomly taken, oven-dried for $48 \mathrm{~h}$ at $40^{\circ} \mathrm{C}$ and then passed through a $2-\mathrm{mm}$ sieve and subjected to water suspensions $(1: 10)$. The substrate electrical conductivity $\left(\mathrm{EC}_{\mathrm{e}}\right)$ and $\mathrm{pH}$ were determined in the water suspension by conductivity meter and $\mathrm{pH}$ meter (models Milwaukee C66 and pH52 (Milwaukee Instruments, USA), respectively). The nitrogen and phosphorus concentrations were determined in substrate water suspensions by HPLC as described by Csáky and Martínez-Grau (1998).

\subsection{Nutrients uptake by plants}

The oven-dried samples taken prior to the start of the treatments and at the end of the experiment were ground in a mill and divided in two subsamples. The analysis of soluble ionic form $\left(\mathrm{NO}_{3}{ }^{-}\right)$in below and aboveground biomass was determined in one subsample following water extraction by HPLC (High Performance Liquid Cromatography; model Metrohm 883 Basic IC Plus, anions ion exchange column model Metrosep A SUPP 4, IC conductivity detector range $\left(0-15000 \mu \mathrm{S} \mathrm{cm}^{-1}\right)$, Metrohm AG, Switzerland) as described by Csáky and Martínez-Grau (1998). The other subsample was digested with sulphuric acid $\left(\mathrm{H}_{2} \mathrm{SO}_{4}, 96 \%\right)$ in the presence of hydrogen peroxide $\left(\mathrm{H}_{2} \mathrm{O}_{2}, 30 \%(\mathrm{w} / \mathrm{v})\right.$ and $\mathrm{P}$-free $)$ at $300^{\circ} \mathrm{C}$ and used for the determination of organic N. The organic $\mathrm{N}$ concentration was quantified colorimetrically (model Shimadzu UV-1201, Shimadzu, Japan) at $630 \mathrm{~nm}$ (Krom, 1980) and the total P concen- tration was quantified colorimetrically by the molybdo-vanadate method at $430 \mathrm{~nm}$ (Hogue et al., 1970). The total $\mathrm{N}$ concentration was calculated as the sum of the organic $\mathrm{N}$ and $\mathrm{NO}_{3}{ }^{-}$concentration. The nutrient uptake (NU) in plants prior to the start of the treatments and at the end of the experiment was calculated by the following equation:

$N U=\left\lceil\left(D W_{B G} * C_{B G}+D W_{A G} * C_{A G}\right)\right\rceil * D$

Where:

DW: dry weight $(\mathrm{g})$ of belowground ${ }_{B G}$ ) or aboveground biomass (AG)

$\mathrm{C}$ : nutrient concentration ( $\mathrm{mg}$ nutrient $\mathrm{g}^{-1} \mathrm{DW}$ ) in belowground $(B G)$ or aboveground biomass $(A G)$

D: Planting density (number of plants $\mathrm{m}^{-2}$ )

\subsection{Relations between the plant parameters and the nutrient use efficiency}

At the end of the trial, the relationships between the growth and nutrient parameters of Juncus plants and the EC of nutrient solutions were tested by regression analysis and the best fitted models were selected based on the determination coefficient $\left(R^{2}\right)$. The nutrients use efficiencies for each treatment were calculated as the difference between plant dry weight (in $\mathrm{g}$ ) per amount of nutrient supplied (in $g$ ) during the experimental period.

\subsection{Statistical analysis}

The experiment was analysed as a completely randomized block design, and the values obtained for each plant and each variable were considered as independent replicates. The Analyses of Variance (ANOVA) and the least significant difference (LSD) tests $(\mathrm{P}<0.05)$ were used to assess the differences between treatments. All statistical analyses were performed using Statgraphics Plus Software (version 5.1.).

\section{Results}

\subsection{Plant parameters and biomass}

Throughout the experiment, there were no mortalities of Juncus plants or tissue damage attributed to the tested treatments. The irrigation with different nutrient solutions increased significantly the plant height, number of culms and the fresh and dry weight of belowground, aboveground and total plant in final plants (Tf) 
Table 2

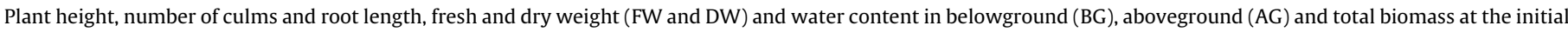

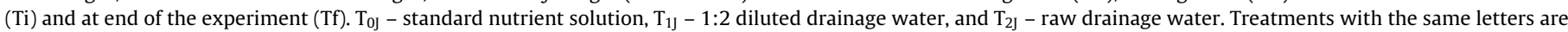
not significantly different at $P<0.05$ (ANOVA and LSD test). ns: not significant. Data are the means \pm standard deviation of four plants per treatment.

\begin{tabular}{|c|c|c|c|c|c|}
\hline \multirow[t]{2}{*}{$\mathrm{Ti}$} & & & \multicolumn{3}{|l|}{ Tf } \\
\hline & & & $\mathrm{T}_{0 \mathrm{~J}}$ & $\mathrm{~T}_{1 \mathrm{~J}}$ & $\mathrm{~T}_{2 \mathrm{~J}}$ \\
\hline Plant height $(\mathrm{cm})$ & & $46.00 \pm 1.05 \mathrm{~d}$ & $52.00 \pm 2.65 c$ & $56.00 \pm 1.00 \mathrm{~b}$ & $61.67 \pm 0.58 \mathrm{a}$ \\
\hline Number of culms & & $27.20 \pm 1.12 \mathrm{~d}$ & $31.33 \pm 2.52 c$ & $55.33 \pm 2.08 \mathrm{~b}$ & $79.00 \pm 3.46 \mathrm{a}$ \\
\hline Root length (cm) & & $17.75 \pm 1.30 \mathrm{~b}$ & $27.75 \pm 1.50 \mathrm{a}$ & $19.00 \pm 1.73 b$ & $18.67 \pm 0.58 b$ \\
\hline \multirow[t]{3}{*}{$\mathrm{FW}\left(\mathrm{g} \mathrm{m}^{-2}\right)$} & BG & $173.30 \pm 10.01 \mathrm{~d}$ & $210.56 \pm 13.32 \mathrm{c}$ & $263.40 \pm 22.21 b$ & $590.03 \pm 57.24 \mathrm{a}$ \\
\hline & AG & $240.42 \pm 15.67 \mathrm{~d}$ & $278.35 \pm 16.97 \mathrm{c}$ & $670.94 \pm 39.59 \mathrm{~b}$ & $787.32 \pm 47.78 \mathrm{a}$ \\
\hline & Total & $416.24 \pm 24.45 \mathrm{~d}$ & $490.28 \pm 26.93 c$ & $934.47 \pm 71.59 b$ & $1378.75 \pm 113.02 \mathrm{a}$ \\
\hline \multirow[t]{3}{*}{$\mathrm{DW}\left(\mathrm{g} \mathrm{m}^{-2}\right)$} & BG & $35.91 \pm 1.80 \mathrm{~d}$ & $44.49 \pm 2.47 \mathrm{c}$ & $70.27 \pm 3.70 \mathrm{~b}$ & $150.02 \pm 10.20 \mathrm{a}$ \\
\hline & AG & $100.86 \pm 8.25 \mathrm{~d}$ & $121.42 \pm 8.98 \mathrm{c}$ & $241.37 \pm 11.65 b$ & $269.38 \pm 11.35 \mathrm{a}$ \\
\hline & Total & $136.06 \pm 9.58 \mathrm{~d}$ & $168.02 \pm 6.54 \mathrm{c}$ & $314.37 \pm 22.98 b$ & $419.52 \pm 35.44 \mathrm{a}$ \\
\hline \multirow[t]{3}{*}{ Water content } & BG & $0.83 \pm 0.06 \mathrm{~ns}$ & $0.76 \pm 0.02 \mathrm{~ns}$ & $0.78 \pm 0.02 \mathrm{~ns}$ & $0.75 \pm 0.01 \mathrm{~ns}$ \\
\hline & $\mathrm{AG}$ & $0.57 \pm 0.09 \mathrm{~ns}$ & $0.61 \pm 0.06 \mathrm{~ns}$ & $0.65 \pm 0.04 \mathrm{~ns}$ & $0.63 \pm 0.07 \mathrm{~ns}$ \\
\hline & Total & $0.67 \pm 0.05 \mathrm{~ns}$ & $0.68 \pm 0.03 \mathrm{~ns}$ & $0.68 \pm 0.03 \mathrm{~ns}$ & $0.69 \pm 0.04 \mathrm{~ns}$ \\
\hline
\end{tabular}

Table 3

Effects of the treatments on $\mathrm{pH}$, electrical conductivity $\left(\mathrm{EC}_{\mathrm{e}}\right)$, and $\mathrm{N}$ and $\mathrm{P}$ concentrations of the substrate at the end of the experiment (Tf). $\mathrm{T}_{0 \mathrm{j}}$ - standard nutrient solution, $\mathrm{T}_{1 \mathrm{~J}}-1: 2$ diluted drainage water, and $\mathrm{T}_{2 \mathrm{~J}}$ - raw drainage water. The initial values were also presented ( $\mathrm{Ti}$ ). In a row, treatments with the same letters are not significantly different at $P<0.05$ (ANOVA and LSD test). Data are the means \pm standard deviation of four substrate samples per treatment.

\begin{tabular}{lllll}
\hline \multirow{2}{*}{$\mathrm{Ti}$} & \multicolumn{4}{l}{$\mathrm{Tf}$} \\
\cline { 2 - 5 } & & $\mathrm{T}_{0 \mathrm{~J}}$ & $\mathrm{~T}_{1 \mathrm{~J}}$ & $\mathrm{~T}_{2 \mathrm{~J}}$ \\
\hline $\mathrm{EC}_{\mathrm{e}}\left(\mathrm{mS} \mathrm{m}^{-1}\right)$ & $130 \pm 10 \mathrm{c}$ & $126 \pm 12 \mathrm{c}$ & $209 \pm 18 \mathrm{~b}$ & $362 \pm 29 \mathrm{a}$ \\
$\mathrm{pH}_{(\mathrm{H} 2 \mathrm{O})}$ & $7.0 \pm 0.36 \mathrm{~b}$ & $6.8 \pm 0.22 \mathrm{~b}$ & $7.9 \pm 0.13 \mathrm{a}$ & $8.0 \pm 0.08 \mathrm{a}$ \\
$\mathrm{N}\left(\mathrm{mg} \mathrm{Kg}^{-1}\right)$ & $1014.2 \pm 96.20 \mathrm{a}$ & $805.2 \pm 56.80 \mathrm{~b}$ & $491.0 \pm 64.12 \mathrm{c}$ & $501.3 \pm 87.60 \mathrm{c}$ \\
$\mathrm{P}\left(\mathrm{mg} \mathrm{Kg}^{-1}\right)$ & $90.80 \pm 6.35 \mathrm{a}$ & $74.94 \pm 6.29 \mathrm{~b}$ & $51.93 \pm 7.06 \mathrm{c}$ & $46.40 \pm 6.96 \mathrm{c}$ \\
\hline
\end{tabular}

compared to the initial plants (Ti). Additionally, the irrigation with diluted $\left(\mathrm{T}_{1 \mathrm{~J}}\right)$ and raw drainage water $\left(\mathrm{T}_{2 \mathrm{~J}}\right)$ increased significantly the plant height (1.1 and 1.2-times, respectively), the number of culms (1.8 and 2.5-times, respectively) and the fresh and dry weight of total plant (1.9 and 2.6-times, respectively) compared to the control treatment $\left(\mathrm{T}_{0 \mathrm{~J}}\right)$. Nevertheless, the root length showed the highest value in plants irrigated with the control treatment $\left(\mathrm{T}_{0 \mathrm{~J}}\right)$ and the water content remained without significant differences under the irrigation with the different nutrient solutions (Table 2).

\subsection{Substrate parameters}

At the end of the experiment, the $\mathrm{pH}$ value of the substrate significantly increased in diluted and raw drainage water treatments $\left(\mathrm{T}_{1 \mathrm{~J}}\right.$ and $\left.\mathrm{T}_{2 \mathrm{~J}}\right)$ compared to the control treatment $\left(\mathrm{T}_{2 \mathrm{~J}}\right)$ but without statistical differences between them. As can be expected, the $\mathrm{EC}_{\mathrm{e}}$ of the substrate irrigated with raw drainage water $\left(\mathrm{T}_{2 \mathrm{~J}}\right)$ showed the highest value mainly due to the accumulation of $\mathrm{Na}$ and $\mathrm{Cl}$ (data not presented). The concentration of $\mathrm{N}$ and $\mathrm{P}$ in the substrate decreased significantly in all the treatments at the end of the experiment showing the lowest values in diluted and raw drainage water $\left(\mathrm{T}_{1 \mathrm{~J}}\right.$ and $\left.\mathrm{T}_{2 \mathrm{~J}}\right)$ (Table 3 ).

\subsection{Nutrient uptake}

The irrigation with different nutrients solutions increased significantly the total $\mathrm{N}$ and $\mathrm{P}$ uptake in belowground, aboveground and total biomass in plants at the end of the experiment $\left(T_{0 \mathrm{~J}}, \mathrm{~T}_{1 \mathrm{~J}}\right.$ and $\mathrm{T}_{2 \mathrm{~J}}$ ) compared to the initial plants (Ti). Moreover, the irrigation with diluted $\left(\mathrm{T}_{1 \mathrm{~J}}\right)$ and raw drainage water $\left(\mathrm{T}_{2 \mathrm{~J}}\right)$ increased significantly the TN and TP uptake in belowground, aboveground and total biomass compared to the control treatment $\left(\mathrm{T}_{0 \mathrm{~J}}\right)$, showing
Table 4

Nutrient use efficiency of plants irrigated with different treatments at the end of the experiment. $\mathrm{T}_{0 \mathrm{~J}}$ - standard nutrient solution, $\mathrm{T}_{1 \mathrm{j}}-1: 2$ diluted drainage water and $\mathrm{T}_{2 \mathrm{~J}}$ - raw drainage water. Treatments with the same letters are not significantly different at $P<0.05$ (ANOVA and LSD test). ns: not significant. Data are the means \pm standard deviation of four plants per treatment.

\begin{tabular}{llll}
\hline Nutrient use & & & \\
\hline efficiency & $\mathrm{T}_{0 \mathrm{~J}}$ & $\mathrm{~T}_{1 \mathrm{~J}}$ & $\mathrm{~T}_{2 \mathrm{~J}}$ \\
\hline NUE & $10.70 \pm 1.07 \mathrm{c}$ & $99.81 \pm 9.19 \mathrm{~b}$ & $123.15 \pm 12.32 \mathrm{a}$ \\
PUE & $37.80 \pm 3.22 \mathrm{c}$ & $890.84 \pm 86.54 \mathrm{~b}$ & $1164.48 \pm 91.82 \mathrm{a}$ \\
ClUE & $6.6 \pm 0.61 \mathrm{a}$ & $4.65 \pm 0.41 \mathrm{~b}$ & $3.11 \pm 0.31 \mathrm{c}$ \\
SUE & $12.88 \pm 1.31 \mathrm{~b}$ & $35.69 \pm 3.56 \mathrm{a}$ & $40.73 \pm 4.10 \mathrm{a}$ \\
CaUE & $10.30 \pm 1.04 \mathrm{~ns}$ & $9.44 \pm 0.91 \mathrm{~ns}$ & $11.06 \pm 1.01 \mathrm{~ns}$ \\
MgUE & $24.45 \pm 2.39 \mathrm{~b}$ & $36.24 \pm 3.02 \mathrm{a}$ & $40.26 \pm 4.02 \mathrm{a}$ \\
KUE & $6.96 \pm 0.71 \mathrm{~b}$ & $22.53 \pm 2.52 \mathrm{a}$ & $25.15 \pm 2.62 \mathrm{a}$ \\
NaUE & $13.90 \pm 1.25 \mathrm{a}$ & $8.96 \pm 0.81 \mathrm{~b}$ & $6.37 \pm 0.61 \mathrm{c}$ \\
\hline
\end{tabular}

the plants irrigated with raw drainage water the highest TN and TP uptake (Fig. 2A and B).

\subsection{Correlation models between growth-nutrient parameters and $E C$}

The different parameters observed in J. acutus plants were related to the $\mathrm{EC}$ of the nutrient solution at the end of the trial. The best fitted models (those with the largest $\mathrm{R}^{2}$ value) were polynomials models. All the parameters studied showed a high correlation with the increasing of EC in nutrient solution. The plant height and number of culms reached a maximum value to $310 \mathrm{mS} \mathrm{m}^{-1}$, whereas the root length showed the lowest value at this EC (Fig. 3A). In terms of biomass, the total FW and DW showed a high raise with increasing EC (Fig. 3B) and the total $\mathrm{N}$ and $\mathrm{P}$ uptake were enhanced when EC was gradually raised (Fig. $3 \mathrm{C}$ and D).

As can be expected, the NUE and PUE ratios increased significantly in plants irrigated with diluted and raw drainage water $\left(\mathrm{T}_{1 \mathrm{~J}}\right.$ and $\left.\mathrm{T}_{2 \mathrm{~J}}\right)$ compared to the control treatment $\left(\mathrm{T}_{0 \mathrm{~J}}\right)$, whereas the CIUE and NaUE ratios showed an opposite trend with NUE and PUE ratios declining significantly in diluted and raw drainage water treatments $\left(\mathrm{T}_{1 \mathrm{~J}}\right.$ and $\left.\mathrm{T}_{2 \mathrm{~J}}\right)$ compared to the control treatment $\left(\mathrm{T}_{0 \mathrm{~J}}\right)$. On the other hand, the SUE, MgUE and KUE ratios increased with drainage water treatments (diluted $\left(\mathrm{T}_{1 \mathrm{~J}}\right)$ and raw $\left(\mathrm{T}_{2 \mathrm{~J}}\right)$ ) compared to the control treatment $\left(\mathrm{T}_{0 \mathrm{~J}}\right)$ but without statistical differences between them, and the CaUE ratio remained without statistical differences under the irrigation with different nutrient solution treatments (Table 4). 
A

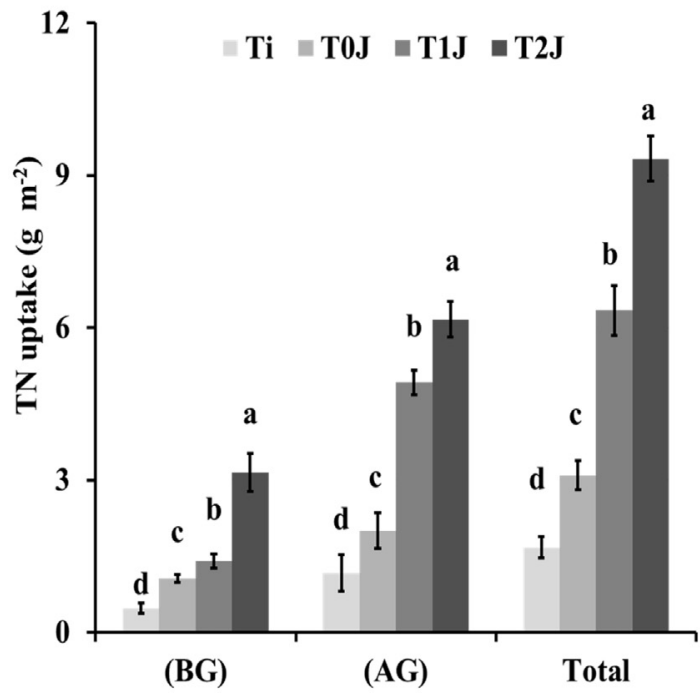

B

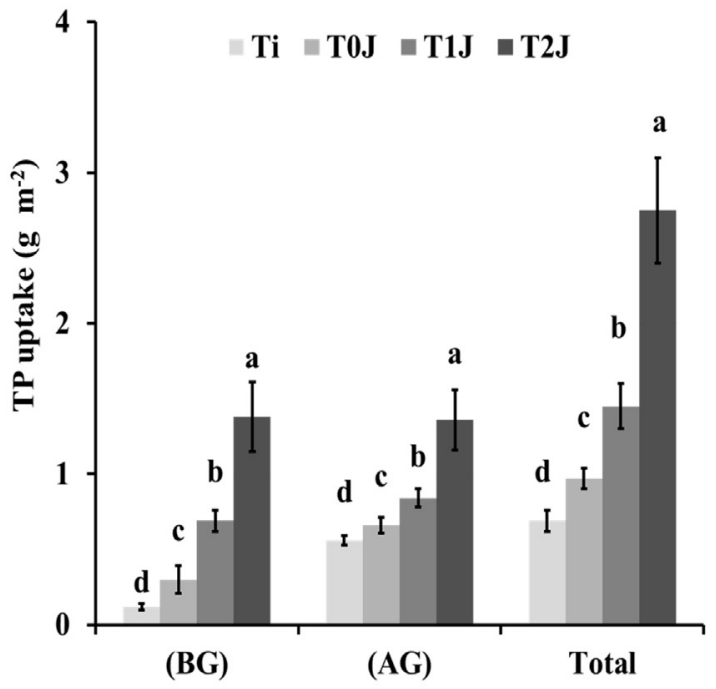

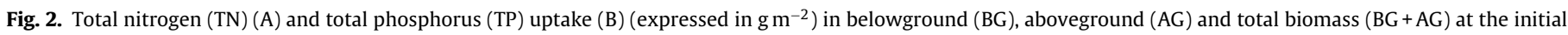

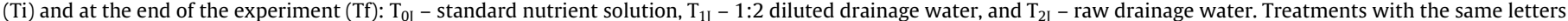
are not significantly different at $P<0.05$ (ANOVA and LSD test). Data are the means \pm standard deviation of four plants per treatment.

\section{Discussion}

The research on biological resources used as tools for managing the nursery pollution can be one of the fundamental guidelines for the design and development of effective methodologies for the environmental phytoremediation. Hence, the location of native species with a high capacity for the nitrogen and phosphorus uptake and for the growth in the leachates can be of paramount importance for the remediation of the drainage pollution from the container grown plants (Broschat, 1995).

Our experimental results demonstrate that the increase of plant height and number of culms and consequently the increase of fresh and dry weight of belowground, aboveground and total biomass in plants irrigated with diluted $\left(\mathrm{T}_{1 \mathrm{~J}}\right)$ and raw drainage water treatments $\left(\mathrm{T}_{2 \mathrm{~J}}\right)$ compared to the control treatment $\left(\mathrm{T}_{0 \mathrm{~J}}\right)$. This increase can be related with the slight increase of EC in each treatment due to the accumulation of $\mathrm{Na}^{+}$and $\mathrm{Cl}^{-}$in the nutrient solution by the reuse of drainage in the ornamental cascade cropping system, where the plants irrigated with raw drainage water $\left(T_{2 J}\right)$ showed the highest value for all the parameters previously commented. The increase of the plant height and number of culms related with the EC increase in the nutrient solution agrees very well with Twilley and Barko (1990) who reported an increase of plant height in other macrophytes plants as Myriophyllum spicatum and Potamogeton perfoliatus irrigated with increasing salinity levels near to $1875 \mathrm{mS} \mathrm{m}^{-1}$. Nevertheless other researchers reported a reduction of the plant height and number of culms under increasing salinity in species within Juncaceae such as J. acutus grown at $1560 \mathrm{mS} \mathrm{m}^{-1}$ (Greenwood and MacFarlane, 2009) and J. kraussii grown at $10000 \mathrm{mS} \mathrm{m}^{-1}$ (Lymbery et al., 2006).

In our experiment, there was no clear trend between the root length and irrigation with different nutrient solutions. Plants irrigated with a standard nutrient solution $\left(\mathrm{T}_{0 \mathrm{~J}}\right.$ ) (lowest level of salinity) showed the highest root length, although their root biomass was lower than the other treatments. This increase of root length can be related with a normal strategy showed in halophytes to maintain the root and rhizome survival through diverting the energy from aboveground to belowground under lower levels of salinity (Craine, 2005). Different results were reported by Rozema and Blom (1977) who noted that the root length of J. gerardii plants increased after six weeks in plants irrigated with 1:2 diluted sea- water compared to the control treatment (irrigation with distilled water).

The fresh and dry weight increase due to the slight increasing of EC obtained in our experiment in J. acutus plants differed from the results reported in other experiments with species within Juncaceae such as J. acutus and J. kraussii (Greenwood and MacFarlane, 2009) and J. acutus and J. maritimus (Boscaiu et al., 2012) where the belowground, aboveground and total biomass in plants decreased with increasing EC.

The irrigation with different nutrient solutions had no effect on the water content in J. acutus plants. Several studies showed a reduction in the water content in J. roemarianus irrigated with artificial sea water $\left(4700 \mathrm{mS} \mathrm{m}^{-1}\right)$ (Touchette et al., 2009), while others researchers reported the increase of water content as a feature frequently performed in many halophytes (Crawford, 1989), representing a very efficient way of mitigation of the adverse osmotic and toxic effects of ions through the dilution.

As can be expected, the increase of biomass in J. acutus plants led to increase the total $\mathrm{N}$ and $\mathrm{P}$ uptake showing a closer relationship $\left(R^{2}=0.89\right.$ and 0.93 , respectively), therefore the highest values of total $\mathrm{N}$ and $\mathrm{P}$ uptake were found in plants irrigated with the raw drainage water $\left(T_{2 J}\right)$, although the nitrate and phosphate concentrations were lower than in the control treatment $\left(\mathrm{T}_{0 \mathrm{~J}}\right)$. Although these results can be unexpected, agreeing very well with the findings reported by Shaver and Melillo (1984) who demonstrated for wetland plant species that the efficiency of $\mathrm{N}$ and $\mathrm{P}$ uptake and the efficiency of their use (biomass produced per unit of $\mathrm{N}$ and $\mathrm{P}$ acquired) tends to increase as available nutrients inputs decrease.

At the end of the trial, the $\mathrm{N}$ standing stocks values in total biomass obtained in our experiment ranged from 3 to $9 \mathrm{~g} \mathrm{~N} \mathrm{~m}^{-2}$ being lower than the values reported in other experiments with macrophytes such as Phragmites australis (20-27 $\mathrm{g} \mathrm{N} \mathrm{m}^{-2}$ ) (MaltaisLandry et al., 2009) and Typha latifolia (29-51 $\mathrm{g} \mathrm{N} \mathrm{m}^{-2}$ ) (Maddison et al., 2009). Concerning to the aboveground $\mathrm{N}$ standing stock values, the ranges reported by other researchers were higher than the range obtained in our experiment (2-6 $\mathrm{g} \mathrm{N} \mathrm{m}^{-2}$ ). Tanner (1996) noted $\mathrm{N}$ standing stocks values in other macrophytes, such as Phragmites australis and Glyceria of 32 and $95 \mathrm{~g} \mathrm{~N} \mathrm{~m}^{-2}$; respectively. Ennabili et al. (1998) reported aboveground N standing stocks values of $11 \mathrm{~g} \mathrm{~N} \mathrm{~m}^{-2}$ in J. acutus grown in wetlands of Morocco and Vymazal (2007) in a review about nutrients removals of macro- 
A)

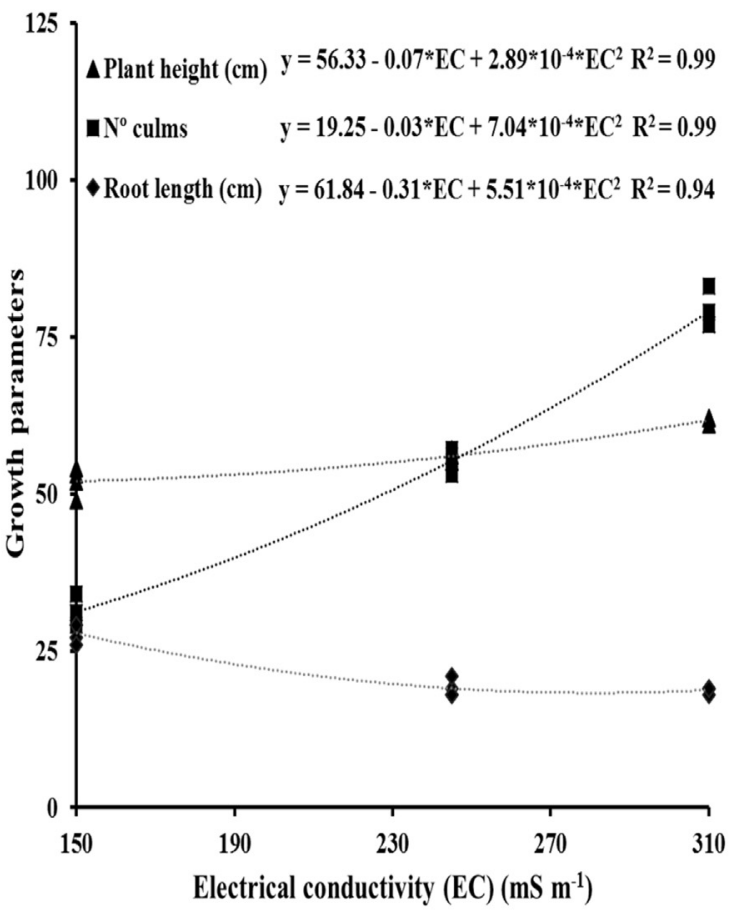

C)

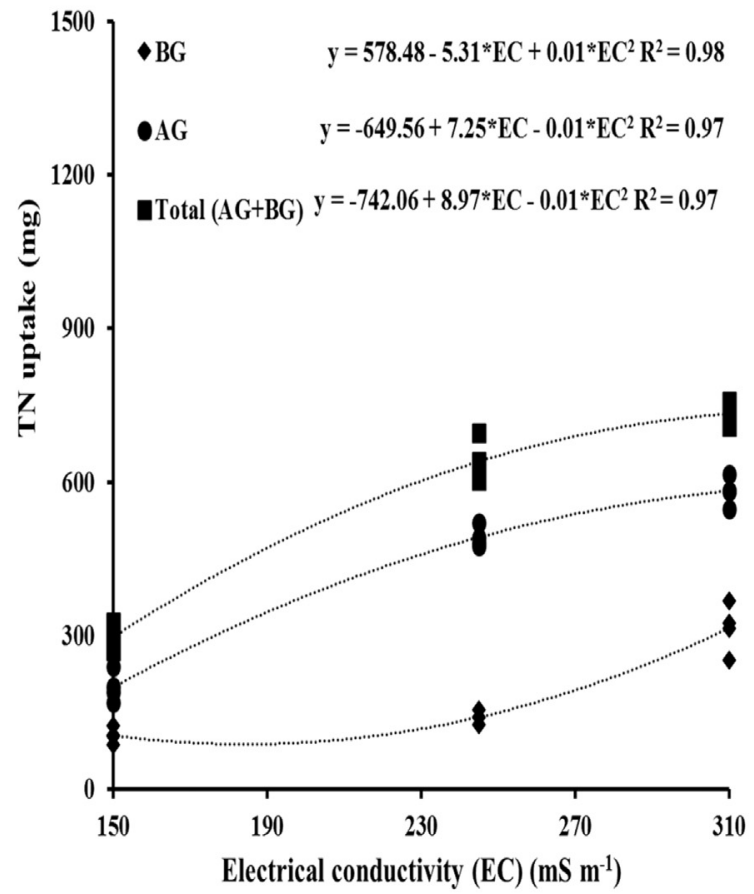

B)

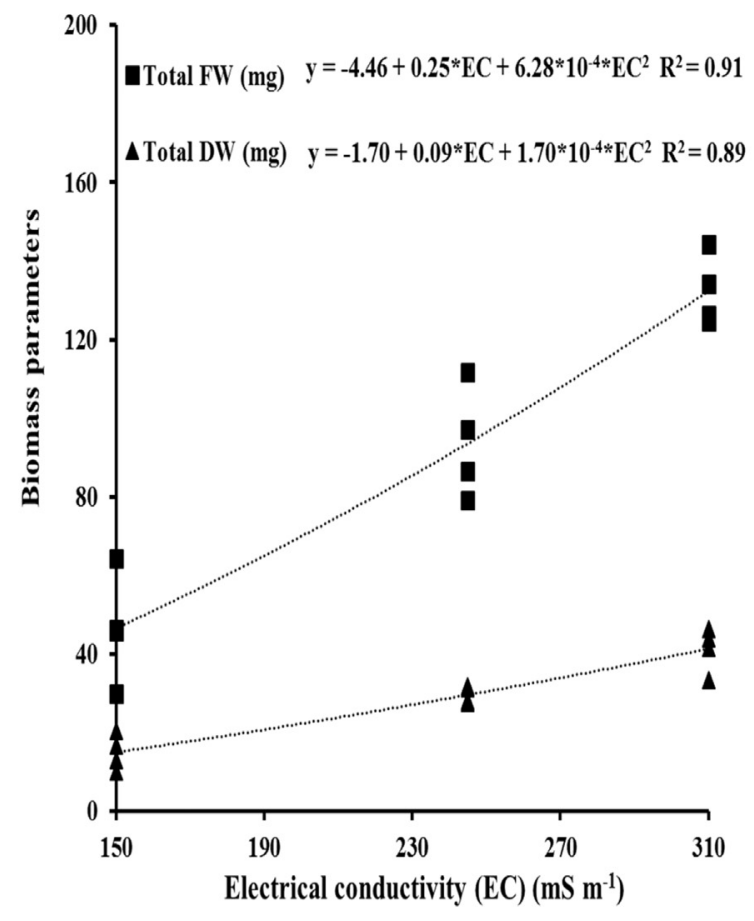

D)

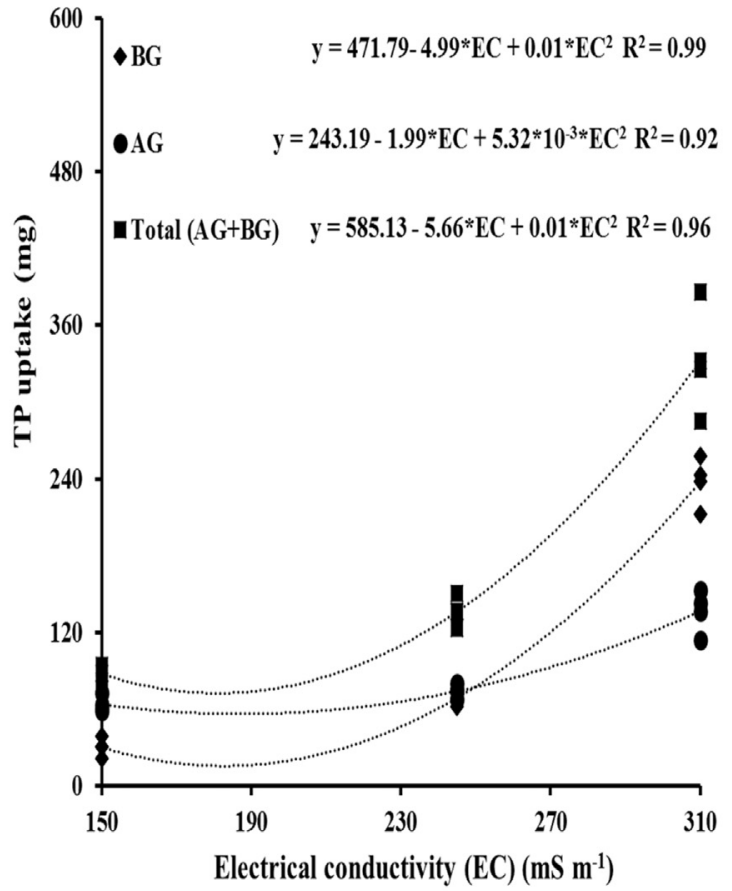

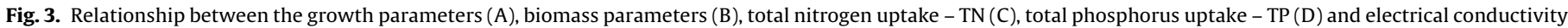
(EC) of the nutrient solution $\left(\mathrm{mS} \mathrm{m}^{-1}\right)$ at the end of the experiment. 
phytes in various types of constructed wetlands reported ranges of 0.6-72 g N m$^{-2}$ (Johnston, 1991), 22-88 g N m${ }^{-2}$ (Vymazal, 1995), 2-64 $\mathrm{g} \mathrm{N} \mathrm{m}^{-2}$ (Vymazal et al., 1999) or 2-29 $\mathrm{g} \mathrm{N} \mathrm{m}^{-2}$ (Mitsch and Gosselink, 2000). Similarly, to the previous results, the range of belowground $\mathrm{N}$ standing stocks values in our experiment $\left(1-3 \mathrm{~g} \mathrm{~N} \mathrm{~m}^{-2}\right)$ was lower compared to the ranges reported by other researchers in other macrophytes such as Typha latifolia $\left(12-19 \mathrm{~g} \mathrm{~N} \mathrm{~m}^{-2}\right.$ ) (Maddison et al., 2009) and Calamograstis angustifolia (12-28 $\mathrm{g} \mathrm{N} \mathrm{m}^{-2}$ ) (Sun and Liu, 2007).

The $\mathrm{P}$ uptake is lower than the $\mathrm{N}$ uptake capacity of macrophytes (Vymazal, 2007) being in accordance with our results, so the aboveground P standing stock values were 4.5-times lower than the aboveground $\mathrm{N}$ standing stock values in the treatment with the highest total $\mathrm{N}$ and $\mathrm{P}$ uptake (raw drainage water $\left(\mathrm{T}_{2 \mathrm{~J}}\right)$ ). The $P$ standing stocks values in total biomass obtained in our experiment ranged from 1.0 to $2.8 \mathrm{~g} \mathrm{P} \mathrm{m}^{-2}$ and were inside from the ranges proposed by other researchers in other macrophytes such as Phragmites australis (2.0-2.6 $\left.\mathrm{g} \mathrm{P} \mathrm{m}^{-2}\right)$ (Haberl and Perfler, 1990) and Phalaris arundinacea $\left(0.5-1.5 \mathrm{~g} \mathrm{P} \mathrm{m}^{-2}\right)$ (Vymazal, 1999) grown in horizontal sub-surface flow beds. Concerning to the aboveground $\mathrm{P}$ standing stock values, the range noted in our experiment $(0.6-1.4 \mathrm{~g}$ $\mathrm{P} \mathrm{m}^{-2}$ ) agrees very well with the value reported by Ennabili et al. (1998) in J. acutus $\left(0.6 \mathrm{~g} \mathrm{P} \mathrm{m}^{-2}\right)$ and $J$. maritimus $\left(0.6 \mathrm{~g} \mathrm{P} \mathrm{m}^{-2}\right)$, but was lower compared to the ranges of aboveground $P$ standing stock values reported by Vymazal (2007) in a review about P removal of macrophytes in constructed wetlands: $0.1-6.8 \mathrm{~g} \mathrm{P} \mathrm{m}^{-2}$ (Johnston, 1991), 0.1-11 g P m$^{-2}$ (Vymazal, 1995), 0.01-19 g P m ${ }^{-2}$ (Vymazal et al., 1999) or 3-15 $\mathrm{g} \mathrm{P} \mathrm{m}^{-2}$ (Brix and Schierup, 1989). The belowground $\mathrm{P}$ standing stock range in our experiment $\left(0.6-1.4 \mathrm{~g} \mathrm{P} \mathrm{m}^{-2}\right)$ was lower compared to the range reported by Kao et al. (2003) in other macrophytes such as J. effusus $\left(0.1-2.0 \mathrm{~g} \mathrm{P} \mathrm{m}^{-2}\right)$ and Phalaris arundinacea $\left(0.1-1.2 \mathrm{~g} \mathrm{P} \mathrm{m}^{-2}\right)$.

The chemical analysis of the substrate at the end of the trial indicated that the $\mathrm{N}$ and $\mathrm{P}$ depletion in the substrate of plants irrigated with diluted and raw drainage water $\left(\mathrm{T}_{1 \mathrm{~J}}\right.$ and $\left.\mathrm{T}_{2 \mathrm{~J}}\right)$ could be related with the higher uptake of $\mathrm{N}$ and $\mathrm{P}$ in those treatments as it was explained above thereby increasing the NUE and PUE as we reported in our results.

According with our results, the irrigation with diluted and raw drainage water $\left(\mathrm{T}_{1 \mathrm{~J}}\right.$ and $\left.\mathrm{T}_{2 \mathrm{~J}}\right)$ with lower concentrations of $\mathrm{N}$ and $P$ compared to the control treatment $\left(\mathrm{T}_{0 \mathrm{~J}}\right)$ supposed an increase of biomass and consequently the increase of $\mathrm{N}$ and $\mathrm{P}$ uptake, where the plants irrigated with higher EC (raw drainage water) showed the highest biomass and total $\mathrm{N}$ and $\mathrm{P}$ uptake and thus the high salinity tolerant macrophytes are good candidates in phytoremediation, because $\mathrm{Na}$ and $\mathrm{Cl}$ were accumulated in the nutrient solution.

\section{References}

Balslev, H., 1996. Juncaceae. Fl neotrópica Monogr 68, 1-167.

Blunk, S.L., Jenkins, B.M., Aldas, R.E., Zhang, R.H., Pan, Z.L., Yu, C.W., Sakr, N.R., Zheng, Y., 2005. Fuel properties and characteristics of saline biomass. ASAE annual international meeting. Bohnert H.J., Nelson,D.E., Jensen, R.G., 1995. Adaptations to environmental stresses. Plant Cell 7, 1099-1111.

Boscaiu, M., Lull, C., Llinares, J., Vicente, O., Boira, H., 2012. Proline as a biochemical marker in relation to the ecology of two halophytic Juncus species. J. Plant Ecol. 6, 177-186.

Brix, H., Schierup, H.H., 1989. The use of macrophytes in water pollution control Ambio 18, 100-107.

Brix, H., 1991. Do macrophytes play a role in constructed treatment wetlands? Water Sci. Technol. 35, 11-17.

Broschat, T.K., 1995. Nitrate, phosphate and potassium leaching from container grown plants fertilized by several methods. HortSci 30, 74-77.

Brown, J.J., Glenn, E.P., Fitzsimmons, K.M., Smith, S.E., 1999. Halophytes for the treatment of saline aquaculture effluent. Aquaculture 175, 255-268.

Carrion, C., Abad, M., Maquieira, A., Puchades, R., Fornes, F., Noguera, V., 2005. Leaching of composts from agricultural wastes to prepare nursery potting media. Acta Hort. 697, 117-124.

Craine, J.M., 2005. Reconciling plant strategy theories of Grime and Tilman. J. Ecol. $93,1041-1052$
Crawford, R.M.M., 1989. Studies in Plant Survival. Blackwell Scientific Publications, Oxford, London, Edinburgh, Boston, Palo Alto, Melbourne.

Csáky, A.G., Martínez-Grau, M.A., 1998. Técnicas Experimentales en Síntesis Orgánica. Ed. Síntesis. Madrid, pp. 255.

EEA (European Environmental Agency), 2005. The integration of environment into EU agriculture policy the IRENA indicator-based assessment report. European Environmental Agency, Copenhagen.

El-Shamy, A.I., Abdel-Razek, A.F., Nassar, M.I., 2012. Phytochemical review of Juncus L. genus (Fam. Juncaceae). Arab. J. Chem., http://dx.doi.org/10.1016/j. arabjc.2012.07.007.

Ennabili, A., Ater, M., Radoux, M., 1998. Biomass production and NPK retention in macrophytes from wetlands of the Tingitan Peninsula. Aquat. Bot. 62, 45-56.

Fernández-Carvajal, M.C., 1982. Revisión del género Juncus L. en la Península Ibérica III. Anales del Jardín Botánico de Madrid, Madrid.

Greenwood, M.E., MacFarlane, G.R., 2009. Effects of salinity on competitive interactions between two Juncus species. Aquat. Bot. 90, 23-29.

Haberl, R., Perfler, R., 1990. 'Seven years of research work and experience with wastewater treatment by a reed bed system'. In: Cooper, P.F., Findlater, B.C. (Eds.), Constructed Wetlands in Water Pollution Control. Pergamon Press Oxford, UK, pp. 205-214.

Handreck, K.A., Black, N.D., 1984. Growing Media for Ornamental Plants and Turf. New South Wales Univ. Press, Kensingtion, Australia.

Hogue, E., Wilcow, G.E., Cantliffe, D.J., 1970. Effect of soil P on phosphate fraction in tomato leaves. J. Am. Soc. Hort. Sci. 95, 174-176.

Incrocci, L., Pardossi, A., Malorgio, F., Maggini, R., Campiotti, C.A., 2003. Cascade cropping system for greenhouse soilless culture. Acta Hort. 609, 297-301.

Jiménez R.M., Caballero, M.R., 1990. El cultivo industrial de plantas en maceta Ed. Horticultura S.L., 664 pp.

Johnston, C.A., 1991. Sediments and nutrient retention by freshwater wetlands: effects on surface water quality. Crit. Rev. Environ. Control 21, 491-565

Kao, J.T., Titus, J.E., Zhu, W.X., 2003. Differential nitrogen and phosphorus retention by five wetland plant species. Wetlands 23, 979-987.

Kim, H., Seagren, E.A., Davis, A.P., 2003. Engineered bioretention for removal of nitrate from stormwater runoff. Water Environ. Res. 75, 355-367.

Krom, M.D., 1980. Spectrophotometric determination of ammonia: study of a modified Berthelot reaction using salicylate and dicholoroisocyanurate. Analyst 105, 305-316.

Lambers, H., 2003. Dry land salinity: a key environmental issue in southern Australia. Plant Soil 257, 5-7.

Lao, M.T., 2005. Leaching in greenhouse cultivation. WFL Publisher. Crops: Quality, Growth and Biotechnology, 406-431.

Lymbery, A.J., Doupé, R.G., Bennett, T., Starcevich, M.R., 2006. Efficacy of a subsurface-flow wetland using the estuarine sedge Juncus kraussii to treat effluent from inland saline aquaculture. Aquacult. Eng. 34, 1-7.

Maddison, M., Soosaar, K., Lõhmus, K., Mander, U., 2009. Cattail population in wastewater treatment wetlands in Estonia: biomass production, retention of nutrients, and heavy metals in phytomass. J. Environ. Sci. Health Part A 40, 1157-1166.

Maltais-Landry, G., Maranger, R., Brisson, J., Chazarenc, F., 2009. Nitrogen transformations and retention in planted and artificially aerated constructed wetlands. Water Res. 43, 535-545.

Mateos-Naranjo, E., Castellanos, E.M., Pérez-Martín, A., 2014. Zinc tolerance and accumulation in the halophytic species Juncus acutus. Env. Exp. Bot. 100, 114-121.

Merhaut, D.J., Blythe, E.K., Newman, J.P., Albano, J.P., 2006. Nutrient release from controlled-release fertilizers in acid substrate in a greenhouse environment: I. Leachate electrical conductivity, $\mathrm{pH}$, and nitrogen, phosphorus and potassium concentrations. HortSci 41, 780-787.

Mitsch, W.J., Gosselink, J.G., 2000. Wetlands. Van Nostrand Reinhold Company, New York (920 pp).

Mufarrege, M.M., Di Luca, G.A., Hadad, H.R., Maine, M.A., 2011. Adaptability of Typha domingensis to high $\mathrm{pH}$ and salinity. Ecotox 20, 457-465.

Read, J., Wevill, T., Fletcher, T., Deletic, A., 2008. Variation among plant species in pollutant removal from stormwater in biofiltration systems. Water Res. 42 893-902.

Rozema, J., Blom, B., 1977. Effects of salinity and inundation on the growth of Agrostis stolonifera and Juncus gerardii. J. Ecol. 65, 213-222.

Sainz, A., Ruiz, F., 2006. Influence of the very polluted inputs of the Tinto-Odiel system on the adjacent littoral sediments of southwestern Spain: a statistical approach. Chemosphere 62, 1612-1622.

Shaver, G.R., Melillo, J.M., 1984. Nutrient budgets of marsh plants: efficiency concepts and relation to availability. Ecology 65, 1491-1510.

Sun, Z., Liu, J., 2007. Nitrogen cycling of atmosphere-plant-soil system in the typical Calamagrostis angustifolia wetland in the Sanjiang Plain, Northeast China. J. Environ. Sci. 19, 986-995.

Tanner, C.C., 1996. Plants for constructed wetland treatment systems A comparison of the growth and nutrient uptake of eight emergent species. Ecol. Eng. 7, 59-83.

Taylor, G.D., Fletcher, T.D., Wong, T.H.F., Breen, P.F., Duncan, H.P., 2005. Nitrogen composition in urban runoff -implications for stormwater management. Water Res. 39, 1982-1989.

Touchette, B.W., Smith, G.A., Rhodes, K.L., Poole, M., 2009. Tolerance and avoidance: two contrasting physiological responses to salt stress in mature marsh halophytes Juncus roemerianus Scheele and Spartina alterniflora Loisel. J. Exp. Mar. Bio. Ecol. 380, 106-112. 
Twilley, R.R., Barko, J.W., 1990. The growth of submersed macrophytes under experimental salinity and light conditions. Estuaries 13, 311-321.

Vymazal, J., Dušek, J., Květ, J., 1999. Nutrient uptake and storage by plants in constructed wetlands with horizontal sub-surface flow: a comparative study. In: Vymazal, J. (Ed.), Nutrient Cycling and Retention in Natural and Constructed Wetlands. The Netherlands Backhuys Publishers, Leiden, pp. 85-100.

Vymazal, J., 1995. Algae and Element Cycling in Wetlands. Lewis Publishers, Chelsea, Michigan (698 pp).
Vymazal, J., 1999. Removal of phosphorus in constructed wetlands with horizontal sub-surface flow in the Czech Republic. In: Vymazal, J. (Ed.), Nutrient Cycling and Retention in Natural and Constructed Wetlands. The Netherlands Backhuys Publishers, Leiden, pp. 73-83.

Vymazal, J., 2007. Removal of nutrients in various types of constructed wetlands. Sci. Total Environ. 380, 48-65.

Yeager, T.H., Barrett, J.E., 1984. Phosphorus leaching from 32P-superphosphate-amended soilless container media. HortSci 19, 216-217. 